\title{
Effects of Pegagan (Centella asiatica (L.)) Powder Addition on Chemical Substances of Pegagan Sticks
}

\author{
Laili Hidayati $^{1^{*},}$ Mazarina ${ }^{2,}$ Devi Issutarti ${ }^{3}$. \\ ${ }^{1,2,3}$ Department of Industrial Technology, Faculty of Engineering, Universitas Negeri Malang
}

\begin{abstract}
The purpose of this study is to analyze the chemical contents (protein, fat, crude fiber, water, ash, and carbohydrates) of sticks made of Pegagan powder. Data were analyzed using ANOVA and continued with DMRT Test if there were differences. There were 70 Panelists in this study. The results showed that the highest level of protein obtained by Pegagan sticks with $10 \%$ addition of Pegagan valued $13.187 \%$, the highest level of fat obtained by Pegagan sticks with 5\% addition valued $12.759 \%$, the highest level of crude fiber obtained by Pegagan sticks with $10 \%$ addition valued $0.847 \%$, the highest level of water obtained by Pegagan sticks with 10\% addition valued $1.969 \%$, the highest level of ash obtained Pegagan sticks with $10 \%$ addition valued $1.271 \%$, and the highest level of carbohydrate obtained Pegagan sticks with 5\% addition valued $71.843(\mathrm{mg} / 100 \mathrm{gr})$.
\end{abstract}

Keywords: Pegagan (Centella asiatica (L.)), Pegagan sticks

\section{INTRODUCTION}

Stick is one of the snack products belong to cookies with low water content so that it has a high shelf life. Sticks are widely consumed by people in rural areas and in cities as well. According to the data from the Statistics Center Agency (Badan Pusat Statistik) in 2014, the average consumption of pastries and cookies in Indonesia reached 0.195 ounces per capita per week in urban areas and 0.146 ounces per capita per week in rural areas. In 2015, there was a consumption increase in pastries and cookies with an average of 0.421 ounces per capita per week in urban areas and 0.284 ounces per capita per week in rural areas. Stick has a crispy texture and has a savory taste. Sticks made of low-sugar dough and through making process to produce a crunchy and characterized product (Manley, 2001: 37). Sticks can be consumed by people from various ages from children to the elderly.

Sticks with the addition of mustard, carrot and spinach powder can increase water, ash, protein, and fat content, and dietery fiber of the sticks as well (Friska, 2002). The addition of dried sweet leaves (Sauropus Androgynus) significantly affected the levels of calcium, protein, crude fiber, and carbohydrate content of the sticks, but this did not significantly affect water, fat, and ash content, and also physical characteristic (hardness) of the sticks (Noviati, 2002).

Stick products added with vegetable powder can increase the nutritional value and active food substances so that they become functional food. "Functional food is processed food that contains one or more functional components in which, based on scientific studies, it has certain physiological functions, is proven to be harmless and beneficial to health" (Food and Drug Monitoring Agency/ Badan Pengawas Obat dan Makanan RI, 2005). Stick is a kind of popular food in the society. Therefore, it can be added by Pegagan powder to increase nutrients and non-nutrients so that it becomes a functional food that is beneficial to health.

Pegagan (Centellaasiatica (L.) is one of the herbal plants that can be used in food and drinks (Hasyim, 2011). Pegagan is famous in every country so that it has a different name like gotu kola is a name for Asiatitic pennywort in India and Nepal (Tawiri et al, 2011), boubok is the name of Asiatitic pennywort in Thailand (Chaiwanichsiri et al, 2000). According to Joshi and Chaturvedi (2013), Asiatitic pennywort in the USA is called (Indian pennywort/ marshy pennywort), Hawaii (pohekula), Cook Island (kapukapi), Fiji (totodro), China (fo-ti-tieng/ chi-hsueuh-tsao), Samoa and Tonga (tono), Tahiti (tohatupaou). In addition, tsubo-kusa is the name of Pegagan in Japan (Peiris and Kays, 1996).

Pegagan traditionally used in Indonesia as a remedy for skin diseases, stomachaches, coughs, bloody coughs, dysentery, wound healing, inflammation, achy rheumatic pain, asthma, hemorrhoids, tuberculosis, leprosy, fever, and appetite enhancer (Food and Drug Monitoring Agency/ Badan Pengawas Obat dan Makanan RI, 2010). Chinese, Indian and Malaysian people use Pegagan to treat various diseases ranging from mental disorders, immune system boosting, circulatory problems, skin problems, liver diseases, epilepsy, asthma, hair loss, and tetanus (Rosalizan et al, 2008). Pegagan extract is also widely used as the main ingredient of drugs and cosmetics in Europe, USA, and Japan (Rosalizan et al, 2008). 
Gotu Kola powder is made from dried Pegagan leaves which are crushed. The drying process of both vegetables and fruits by sunlight and using tools can decrease the nutrients if it is without going through the blanching process (Desrosier, 2008: 197). Blanching is a thermal working process with a temperature of $75-95^{\circ} \mathrm{C}$ for $1-10$ minutes. The blancing process is used for several types of vegetables and fruits before canning, freezing, and drying processes to produce good quality products (Estiasih and Ahmadi, 2011). The purpose of this study is to analyze the chemical contents (protein, fat, water, crude fiber, ash, carbohydrate) of the sticks with Pegagan powder addition.

\section{METHOD}

The research used in making Pegagan sticks was an experimental study. The research design used was a completely randomized design (CRD). Data were analyzed using ANOVA if there were differences followed by DMRT (Duncan Multiple Range Test). There were 70 untrained panelists. vitamin B. indeed, Vellarine content causes bitter taste in Pegagan (Hermawati and Dewi, 2014).

Table 1. Modification and Standard Recipe

\begin{tabular}{lcccc}
\hline \multicolumn{1}{c}{ Ingredient Name } & Control & \multicolumn{3}{c}{ Pegagan Powder Addition } \\
\cline { 3 - 5 } & & $5 \%$ & $7.5 \%$ & $10 \%$ \\
\hline Batter: & & & & \\
Medium protein flour & $500 \mathrm{~g}$ & $475 \mathrm{~g}$ & $462.5 \mathrm{~g}$ & $450 \mathrm{~g}$ \\
Pegagan Powder & - & $25 \mathrm{~g}$ & $37.5 \mathrm{~g}$ & $50 \mathrm{~g}$ \\
Sago flour & $20 \mathrm{~g}$ & $20 \mathrm{~g}$ & $20 \mathrm{~g}$ & $20 \mathrm{~g}$ \\
Margarine & $150 \mathrm{~g}$ & $150 \mathrm{~g}$ & $150 \mathrm{~g}$ & $150 \mathrm{~g}$ \\
Egg & $120 \mathrm{~g}$ & $120 \mathrm{~g}$ & $120 \mathrm{~g}$ & $120 \mathrm{~g}$ \\
Salt & $10 \mathrm{~g}$ & $10 \mathrm{~g}$ & $10 \mathrm{~g}$ & $10 \mathrm{~g}$ \\
Water & $100 \mathrm{~g}$ & $100 \mathrm{~g}$ & $100 \mathrm{~g}$ & $100 \mathrm{~g}$ \\
Cheese & $100 \mathrm{~g}$ & $100 \mathrm{~g}$ & $100 \mathrm{~g}$ & $100 \mathrm{~g}$ \\
& & & & \\
\hline
\end{tabular}

Table 2. Chemical Content Analysis Material

\begin{tabular}{cll}
\hline $\mathrm{No}$ & Type of Analysis & \multicolumn{1}{c}{ Material Name } \\
\hline 1 & Water & Silica gel \\
2 & Protein & $\mathrm{H}_{2} \mathrm{SO}_{4}, \mathrm{Na}_{2} \mathrm{SO}_{4}-\mathrm{HgO}, \mathrm{NaOH}$, methyl red, ethanol, hexane aquades \\
3 & Fat & Silica gel \\
4 & Ash & Phosphate buffer, ethanol, acetone, $\mathrm{NaOH} \mathrm{H}_{2} \mathrm{SO}_{4}, \mathrm{NaOH}_{2} \mathrm{~K}_{2} \mathrm{SO}_{4}$, \\
5 & Crude fiber & Aquades \\
\hline
\end{tabular}

Table 3. Chemical Content Analysis Material

\begin{tabular}{lll}
\hline No & Type of Analysis & Method \\
\hline 1 & Water & Oven \\
2 & Protein & Semi Micro Kjeldahl \\
3 & Fat & Soxhlet \\
4 & Ash & Furnace \\
5 & Crude fiber & Acid-base solvent \\
6 & Carbohydrate & By difference \\
\hline
\end{tabular}


significance value of 0.000 . A value of $p<0.05$ could be interpreted that there was a significant difference in protein levels of the sticks with different addition of Pegagan. Then, this was continued by conducting Duncan's follow-up test, which showed that protein levels of the sticks with Pegagan addition 5\% differed from the addition of $7.5 \%$ and $10 \%$. Meanwhile, the addition of $7.5 \%$ differed from the addition of $5 \%$ and $10 \%$, but the addition of $10 \%$ had the highest protein content.

Table 4. Analysis of Protein Levels in Pegagan

\begin{tabular}{llll}
\hline Sample & Repetition & Protein Levels (\%) & Average (\%) \\
\hline \multirow{2}{*}{ Pegagan Addition 5\% } & 1 & 12.676 & 12.660 \\
Pegagan Addition 7.5\% & 2 & 12.644 & 12.962 \\
Pegagan Addition 10\% & 1 & 12.951 & \\
& 2 & 12.974 & 13.187 \\
\hline
\end{tabular}

The analysis results of fat levels in Pegagan sticks in Table 5 showed that the fat levels of the sticks with Pegagan addition $5 \%$ had an average value of $12.759 \%$, with addition $7.5 \%$ had an average value of $12.164 \%$ and with addition $10 \%$ had an average value of $11.930 \%$. The data obtained were then analyzed using ANOVA. The results of ANOVA in Pegagan sticks at $\alpha=0.05$ had the significance value of 0.000 . $\mathrm{P}$ value $<0.05$ could be interpreted that there was a significant difference in fat levels of the sticks with different addition of Pegagan. Then, this was continued by conducting Duncan's followup test, which showed that fat levels of the sticks with Pegagan addition $10 \%$ differed from the addition of $7.5 \%$ and $5 \%$. Meanwhile, the addition of $7.5 \%$ differed from the addition of $10 \%$ and $5 \%$, but the addition of $10 \%$ had the lowest fat content.

Table 5. Analysis of Fat Levels in Pegagan

\begin{tabular}{llll}
\hline Sample & Repetition & Fat Levels (\%) & Average (\%) \\
\hline \multirow{2}{*}{ Pegagan Addition 5\% } & 1 & 12.774 & 12.759 \\
Pegagan Addition 7.5\% & 2 & 12.744 & \\
Pegagan Addition 10\% & 1 & 12.157 & 12.164 \\
& 2 & 12.171 & \multirow{2}{*}{11.930} \\
\hline
\end{tabular}

The analysis results of crude fiber in Pegagan sticks in Table 6 showed that the crude fiber of the sticks with Pegagan addition $5 \%$ had an average value of $0.473 \%$, with addition $7.5 \%$ had an average value of $0.648 \%$ and with addition $10 \%$ had an average value of $0.847 \%$. The data obtained were then analyzed using ANOVA. The results of ANOVA in Pegagan sticks at $\alpha=0.05$ had the significance value of 0.001 . $\mathrm{P}$ value $<0.05$ could be interpreted that there was a significant difference in crude Table 6. Analysis of Crude Fiber in Pegagan

\begin{tabular}{llll}
\hline Sample & Repetition & Crude Fiber (\%) & Average (\%) \\
\hline Pegagan Addition 5\% & 1 & 0.499 & 0.473 \\
Pegagan Addition 7.5\% & 2 & 0.448 & 0.648 \\
Pegagan Addition 10\% & 1 & 0.646 & 0.847 \\
\hline
\end{tabular}

fiber of the sticks with different addition of Pegagan. Then, this was continued by conducting Duncan's followup test, which showed that crude fiber of the sticks with Pegagan addition 5\% differed from the addition of $7.5 \%$ and $10 \%$. Meanwhile, the addition of $7.5 \%$ differed from the addition of $5 \%$ and $10 \%$, but the addition of $5 \%$ had the lowest crude fiber content. 
interpreted that there was a significant difference in water levels of the sticks with different addition of Pegagan. Then, this was continued by conducting Duncan's followup test, which showed that water levels of the sticks with Pegagan addition 5\% differed from the addition of $7.5 \%$ and $10 \%$. Meanwhile, the addition of $7.5 \%$ differed from the addition of $5 \%$ and $10 \%$, but the addition of $5 \%$ had the lowest water levels.

Table 7. Analysis of Water Levels in Pegagan

\begin{tabular}{lllc}
\hline Sample & Repetition & Water Levels (\%) & Average (\%) \\
\hline \multirow{2}{*}{ Pegagan Addition 5\% } & 1 & 1.740 & 1.742 \\
Pegagan Addition 7.5\% & 2 & 1.745 & \multirow{2}{*}{1.838} \\
Pegagan Addition 10\% & 1 & 1.833 & \multirow{2}{*}{1.969} \\
\hline
\end{tabular}

The analysis results of ash levels in Pegagan sticks in Table 8 showed that the water levels of the sticks with Pegagan addition $5 \%$ had an average value of $1.095 \%$, with addition $7.5 \%$ had an average value of $1.192 \%$ and with addition $10 \%$ had an average value of $1.271 \%$. The data obtained were then analyzed using ANOVA. The results of ANOVA in Pegagan sticks at $\alpha=0.05$ had the significance value of 0.006 . $\mathrm{P}$ value $<0.05$ could be interpreted that there was a significant difference in water levels of the sticks with different addition of Pegagan. Then, this was continued by conducting Duncan's followup test, which showed that ash levels of the sticks with Pegagan addition 5\% differed from the addition of $7.5 \%$ and $10 \%$. Meanwhile, the addition of $7.5 \%$ differed from the addition of $5 \%$ and $10 \%$, but the addition of $5 \%$ had the lowest ash levels.

Table 8. Analysis of Ash Levels in Pegagan

\begin{tabular}{llll}
\hline Sample & Repetition & Ash Levels (\%) & Average (\%) \\
\hline \multirow{2}{*}{ Pegagan Addition 5\% } & 1 & 1.093 & 1.095 \\
Pegagan Addition 7.5\% & 2 & 1.097 & \\
& 1 & 1.189 & 1.192 \\
Pegagan Addition 10\% & 2 & 1.196 & \multirow{2}{*}{1.271} \\
\hline
\end{tabular}

The analysis results of carbohydrate levels in Pegagan sticks in Table 8 showed that the carbohydrate levels of the sticks with Pegagan addition 5\% had an average value of $71.744 \%$, with addition $7.5 \%$ had an average value of $71.843 \%$ and with addition $10 \%$ had an average value of $71.643 \%$. The data obtained were then analyzed using ANOVA. The results of ANOVA in Pegagan sticks at $\alpha=$ 0.05 had the significance value of 0.038 . $\mathrm{P}$ value $<0.05$ could be interpreted that there was a significant difference in carbohydrate levels of the sticks with different addition Table 9. Analysis of Carbohydrate Levels in Pegagan

\begin{tabular}{llll}
\hline Sample & Repetition & Carbohydrate levels (\%) & Average (\%) \\
\hline \multirow{2}{*}{ Pegagan Addition 5\% } & 1 & 71.717 & 71.744 \\
Pegagan Addition 7.5\% & 2 & 71.771 & 71.843 \\
Pegagan Addition 10\% & 1 & 71.870 & 71.643 \\
\hline
\end{tabular}

of Pegagan. Then, this was continued by conducting Duncan's follow-up test, which showed that carbohydrate levels of the sticks with Pegagan addition 10\% did not differ from the addition of $5 \%$ and $7.5 \%$. Meanwhile, the addition of $5 \%$ did not differ from the addition of $7.5 \%$, but the addition of $7.5 \%$ differed from the addition of $10 \%$. The Pegagan addition $7.5 \%$ had the highest carbohydrate levels. 
The ash level in Pegagan sticks with the addition of Pegagan powder $10 \%$ had the highest value.

The difference of ash levels in Pegagan sticks was caused by the ash content contained in Pegagan powder added, because the formulation of the basic ingredients in making sticks did not change. According to the research results, Pegagan powder per $100 \mathrm{~g}$ contained iron $40.52 \mathrm{mg}$, calcium $2697.99 \mathrm{mg}$, and selenium $33.42 \mathrm{mg}$ (Zulya, 2011). The more Pegagan powder added to the Pegagan sticks production, the more ash levels in Pegagan sticks would increase.

Carbohydrates were the main source of energy for the body. Carbohydrates had an important role in determining the characteristics of food ingredients such as taste, color, texture, and others (Winarno, 2003: 15). The determination of carbohydrate levels was analyzed using by difference method, the carbohydrate content was obtained from reducing ash, fat, water, and protein levels. Carbohydrate level of Asaitic pennywort sticks with the addition of Pegagan powder $10 \%$ had the lowest value. This was because the levels of protein, fat, water, and ash in Pegagan sticks increased along with the addition of Asiatic powder so that the amount of carbohydrate levels decreased. The results of the study were in line with the research conducted by Saputri (2014) who stated that carbohydrate levels in Pegagan cookies analyzed by difference decreased with the addition of Asaitic pennywort powder as the protein, fat, water, and ash levels of cookies increased.

\section{CONCLUSION}

The highest protein level attained by Asaitic pennywort sticks with the addition of Pegagan powder $10 \%$ valued $13.187 \%$. The highest fat level attained by Pegagan sticks with the addition of Pegagan powder 5\% valued $12.759 \%$. The highest crude fiber level attained by Asaitic pennywort sticks with the addition of Pegagan powder $10 \%$ valued $0.847 \%$. The highest water level attained by Asaitic pennywort sticks with the addition of Pegagan powder $10 \%$ valued $1.969 \%$. The highest ash level attained by Pegagan sticks with the addition of Pegagan powder $10 \%$ valued $1.272 \%$. The highest carbohydrate level attained by Pegagan sticks with the addition of Pegagan powder 5\% valued 71.843 (mg/100gr).

\section{REFERENCES}

[1] Arsyaf, Annisa Rizki. 2012. Pembuatan Roti Kering (Bagelen) Pegagan (Centella asiatica) Sebagai Pangan Fungsional Untuk Lansia. Skripsi tidak diterbitkan.Bogor: Departemen Gizi Masyarakat IPB

[2] Badan Pengawas Obat dan Makanan RI. 2010. Booklet Pegagan (Centella asiatica (L.) urban). Jakarta: Direktorat OAI, Deputi II, Badan POM RI. (Online)

(perpustakaan.pom.go.id/koleksilainnya/ebook/peg 
Malang: Fakultas Teknologi Pertania UB.

agan.pdf)

[3] Badan Pengawas Obat dan Makanan RI. 2005. Badan Pengawasan Obat dan Makanan Republik Indonesia RI Peraturan Kepala Badan Pengawasan Obat dan Makanan Republik Indonesia Nomor HK 00.05.52.0685. 2005 Tentang Pangan fungsional. Jakarta: Badan Pengawas Obat dan Makanan RI.

[4] Badan Pusat Statistik. 2014. Pengeluaran untuk Konsumsi Penduduk Indonesia. Jakarta: Badan Pusat Statistik Indonesia

[5] Chaiwanichsiri, S., Dharmasuriya, N., Sonthornvit, N. \& Janjarasskul, T. 2000. Process Improverment to Preserve the Color of Instant Pennywort Centella asiatica (Linn.) Urban. Journal Scient Research Chulalongkorn University., Vol. 25., No. 2 (2000)

[6] Desrosier, N. 2008. Teknologi Pengawetan Pangan. Edisi ketiga. Terjemahan Muchji Miljohardjo. Jakarta: Universitas Indonesia (UI Press)

[7] Estiasih, T. \& Ahmadi, K. 2011. Teknologi Pengolahan Pangan. Jakarta: Bumi Aksara

[8] Friska, T. 2002. Penambahan Sayur Bayam (Amaranthus tricolor, L.), Sawi (Brassica juncea, L.) dan Wortel (Daucus carota, L.) pada Pembuatan Crackers Tinggi Serat Makanan. Skripsi tidak diterbitkan. Bogor: Institut Pertanian Bogor

[9] Hasyim, 2011. Centella asiatica in Food and Beverage Applications and its Potential Antioxidant and Neuroprotective Effect. International Food Research Journal 18(4): 12151222 (2011)

[10] Hermawati, R. \& Dewi, H.A. C. 2014. Healty Featnes. Jakata: Fmedia (Imprint Agro Media Pustaka).

[11] Intartia, Nuridatul., Devi, Mazarina dan Hidayati, Laili. 2016. Pengaruh Penambahan Serbuk Pegagan (Centella asitica) dengan Konsentrasi yang Berbeda Terhadap Sifat Fisik, Kimia dan Organoleptik Crackers. Seminar Nasional Jurusan Pendidikan Teknik Boga dan Busana 2016. Universitas Negeri Yogyakarta.

[12] Joshi, K. \& Chaturvedi, P. 2013. Therapeutic Effeciency of Centella asiatica (L) Urban Underutilized Green Leafy Vegetable: an Overview. International Juornal of Pharma and Bio Sciences 2013 Jan; 4(1): (P) 135 - 149

[13] Kustiani, A. 2013. Pengembangan Crackers Sumber Protein dan Mineral dengan Penambahan Tepung Daun Kelor (Moringa oleifera) dan Tepung Badan-Kepala Ikan Lele Dumbo (Clarias gariepinus). Skripsi tidak diterbitkan. Bogor: Institut Pertanian Bogor

[14] Lestari, Puji., Wijana, Susinggih dan Putri, Widelia Ika. 2013. Ekstraksi Tanin Dari Daun Alpukat (Persea Americana Mill.) Sebagai Pewarna Alami (Kajian Proporsi Pelarut Dan Waktu Ekstraksi). Artikel Ilmiah Teknologi Industri Pertanian.
[15] Manley, D. 2001. Biscuits, Crackers and Cookies for the Food Industry. England: Woodhead Publising Ltd. Cambridge

[16] Noviati, A. D. 2002. Pemanfaatan Daun Katuk (Sauropus androgynus) dalam Meningkatkan Kalsium Crackers. Skripsi tidak diterbitkan. Bogor: Institut Pertanian Bogor

[17] Peiris dan Kays, 1996. Pegagan/Centella asiatica (L.) Urb: A Little-Known Vegetable Crop. Hort Techonology. Jan/Mar. 1996(1)

[18] Pratama, R. I., Rostini, I. \& Liviawaty, E. 2014. Karakteristik Biskuit dengan Penambahan Tepung Tulang Ikan Jangilus (Istiophorus Sp.). Jurnal Akuatika Vol. V No. 1/Maret 2014 (30-39) ISSN 0853-2532. Universitas Padjadjaran

[19]Raden, A. 2011. Efek Ekstrak Pegagan (Centella Asiatica) pada Rattus Norvegicus Wistar yang Dilakukan Ovariektomi Terhadap Proliferasi Epitel pada Dinding Vagina. Jurnal Ilmiah Kedokteran Hewan Vol. 4, No. 1.Universitas Negeri Semarang

[20] Restyawati, T. D. 2011. Biscuit Crackers dengan Substitusi Jamur Tiram (Pleurotus ostreatus) sebagai Alternatif Makanan Kecil Berprotein Tinggi. Tugas Akhir tidak diterbitkan. Surakarta: Universitas Sebelas Maret

[21] Rosalizan, M.S., Rohani, M.Y., Khatijah, I. \& Shukri, M.A. 2008. Physical Characteristics, Nutrient Contents and Triterpene Compounds of Ratoon Crops of Centella asiatica at Three Different Stages of Maturity. Journal. Trop. Agric. and Fd. Sc. 36(1)(2008): 43-51

[22] Sait, S., Sumarsi. \& Lubis, E. H. 1992. Potensi Minyak Atsiri sebagai Sumber Bahan Obat. Warta Tumbuhan Obat Indonesia Vol.1 No.2

[23] Saputri, I. 2014. Pengaruh Penambahan Pegagan (Centella asiatica) dengan Berbagai Konsentrasi Terhadap Sifat Fisiko-Kimia Cookies Sagu Antioksidan. Skripsi tidak diterbitkan. Bogor: Institut Pertanian Bogor

[24] Shahwar, D., Shafiq-ur-Rehman, Ahmad, N., Ullah, S., Raza, M.A., 2010, Antioxidant Activities of the Selected Plants from the Family Euphorbiaceae, Lauraceae, Malvaceae and Balsaminaceae, African Journal of Biotechnology, 9(7): 1086-1096.

[25] Tawiri, S., Gehlot, S. \& Gambhir, I. S. 2011. Centella asiatica: a Concise Drug Review With Probable Clinical Uses. Juornal of Stress Physiologt \& Biochemistry, Vol. 7 No. 201, pp. 38-44 ISSN 1997-0838

[26] Winano. 2004. Kimia Pangan dan Gizi. Jakarta: PT Gramedia Pustaka Utama.

[27] Yuniastuti, A. 2010. Peran Pangan Fungional dalam Meningkatkan Derajat Kesehatan.(online). Jurnal Universitas Negeri Semarang. diakses 20 Maret 2015 
[28]Zulya, E. 2011. Formulasi Serbuk Tabur Daun Pegagan (Centella asiatica) pada Mp-Asi sebagai Produk Pangan Fungsional. Tesis tidak diterbitkan. Bogor: Institut Pertanian Bogor

[29]Zheng, C. \& Zin, L. 2007. Chemical Components of Centella asiatica and their Bioactivities. Journal of Chinese Integra Ive Medicine, May 2007; Vol.5 